\title{
Numerical and experimental assessment of a typical brazilian footbridge
}

\section{Avaliação numérica e experimental de uma passarela de pedestre típica brasileira}

G. N. DOZ a

graciela@unb.br

J. L. V. BRITO a

jlbrito@unb.br

A. BRASILIANO

andreabrasiliano@gmail.com

\begin{abstract}
For the range of medium spans, around 30 to $40 \mathrm{~m}$, composite footbridges are getting popular in Brazil. This kind of structure consists on longitudinal steel truss beams providing support for a concrete deck usually made of precast elements. Typical examples of these structures may be found in many cities in Brazil, especially in Brasilia where a large number of highways demanded a significant set of footbridges. Due to the amount of this kind of composite footbridges in Brazil, studies concerning their mechanical behavior are required in order to ensure pedestrian's safety. For this end, in this paper, a typical Brazilian composite footbridge located in Brasilia is analyzed by means of experimental tests and computational modeling. The focus is the determination of natural frequencies and mode shapes. Strategies to correctly obtain the vertical modes are also discussed since vertical vibration is the main vibration problem expected for the tested footbridge. The obtained results showed that structural balance between stiffness and mass leads to natural frequencies out of the critical frequency range excited by pedestrians in normal use, although the idea was not to measure how these parameters, mass or stiffness, could influence the model. Moreover, Finite Element models were evaluated comparing complexity versus accuracy to predict modal parameters.
\end{abstract}

Keywords: numerical analysis, dynamic behavior, footbridge, finite element models.

\section{Resumo}

Para vãos medianos, entre 30 e $40 \mathrm{~m}$, passarelas de pedestres mistas tem se tornado bastante populares no Brasil. Esse tipo de estrutura consiste em treliças e vigas longitudinais de aço que suportam uma plataforma de concreto, usualmente composta por elementos pré-moldados. Exemplos típicos dessas estruturas podem ser encontrados em muitas cidades no Brasil, particularmente em Brasília onde um grande número de rodovias requer um conjunto significativo de passarelas de pedestres. Devido a existência de uma relevante quantidade de estruturas do tipo, passarelas compostas, no Brasil, estudos a respeito de seu comportamento mecânico são necessários a fim de garantir a segurança dos pedestres. Com este propósito, neste artigo, uma passarela de pedestres mista localizada na cidade de Brasília é analisada por meio de testes experimentais e modelagem computacional. $\mathrm{O}$ foco é a determinação das frequências naturais e modos de vibração. Estratégias para a correta obtenção dos modos verticais também são discutidas uma vez que a vibração vertical é o principal problema esperado para a estrutura analisada. Os resultados obtidos mostraram que um equilíbrio entre rigidez e massa leva a frequências naturais fora do intervalo de frequências críticas excitadas pelos pedestres em uso normal, embora a ideia não tenha sido medir como esses parâmetros, massa e rigidez, poderiam influenciar o modelo. Além disso, modelos em elementos finitos foram avaliados comparando complexidade versus precisão para a determinação dos parâmetros modais.

Palavras-chave: análise numérica, comportamento dinâmico, passarela de pedestres, modelos de elementos finitos. 


\section{Introduction}

Vibration serviceability of footbridges has been recognized as a design problem for a long time. One of the first practice codes to deal specifically with the problem was the British Code BS 5400 [1], followed by the Ontario code [2]. In these cases, the adopted approach was the same, focusing on vibrations in the vertical direction and considering the load produced by a single pedestrian crossing the structure in resonance condition as a design load. The acceleration produced in critical points along the span should be smaller than limit values expressed in each code; the Ontario Code [2] adopted limits much stricter than those of the British Code [1]. Over time and in view of advances in research, the design load has evolved from the (artificial) case of a single pedestrian walking in resonance to groups of pedestrians and/or a stream of pedestrians crossing the structure. The current version of UK NA to EN1 [3] code and the HIVOSS guideline [4] are examples of this recent approach. The aforementioned code and guideline also contain procedures to deal with vibrations in lateral direction, due to recent cases of excessive lateral vibration presented in long span footbridges (Dallard et al. [5]; Danbon and Grillaud [6]).

A recognized crucial parameter dealing with this problem is the natural (fundamental) frequency of the structure, either in vertical or in lateral direction. For the case of vertical direction, footbridges are considered to be satisfactory in terms of vibration performance if the fundamental frequency in such direction is above $5 \mathrm{~Hz}$. This value is above the range of the first two harmonics of walking excitation, considering the pedestrian pacing rate as the first harmonic. Pacing rates, in turn, are typically in the range from 1.6 to $2.4 \mathrm{~Hz}$ (Matsumoto et al. [7]). As for the lateral direction, the focus is only the frequency range of the first harmonic of excitation, which is around $1 \mathrm{~Hz}$.

A publication of the CEB [8] shows a strong dependency between the fundamental vertical frequency and the span. An exponential regression function was also proposed in that publication to obtain such a frequency as a function of the span only. This was based on measurements carried out in several footbridges of varied

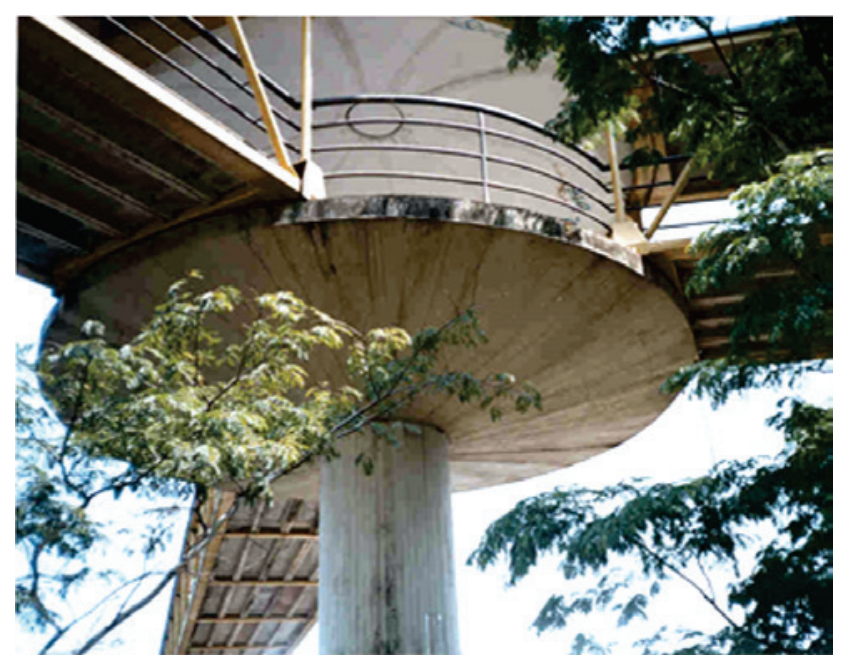

Figure 1

Aerial view of the footbridge under trial

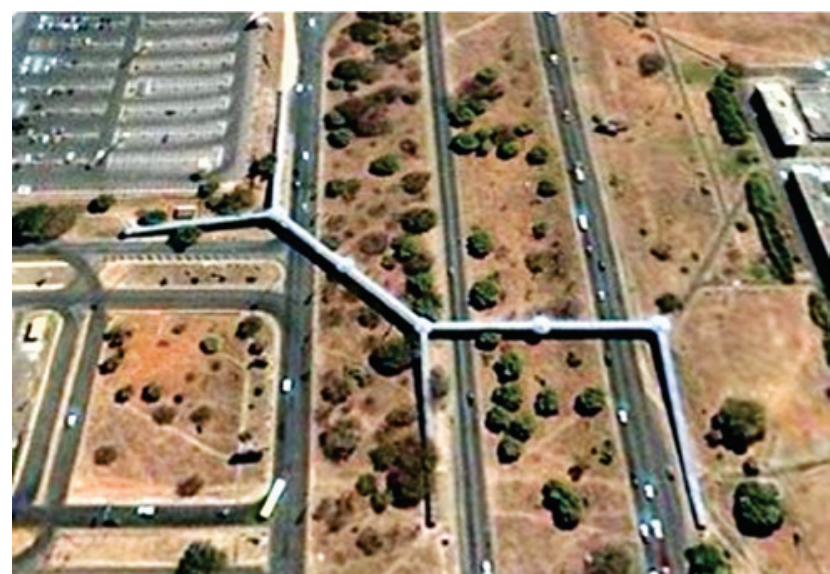

Figure 2

The linking of the access ramps with the horizontal span

structural systems. However, for a given span, the influence of the structural system on frequency is expected, as each structural system has a different balance between stiffness and mass.

In this paper, a particular structural system composed by steel and concrete was investigated. The studied structure consists on longitudinal steel truss beams providing support for a concrete deck made of precast elements. For this end, analysis of the vibration serviceability of the tested composite footbridge is presented, based on two experimental campaigns and computational modeling. The study has been made focusing the structural dynamic behavior and a synthesis of analysis concerning vibration serviceability is presented, aiming to support the evaluation of pedestrians' safety. Since this structural system is not suitable for long spans, the paper is focused on vibrations in the vertical direction. This is because the cases of vibration problems in the lateral direction have occurred in long span footbridges only. However, some results obtained for the lateral direction are also discussed. This kind of research is important since this structural system is gaining popularity in Brazilian cities as a structural solution for medium spans around 30 to 40 meters (Brasiliano et al. [9], Brito et al. [10]).

\section{Analysed structure}

The footbridge under analysis is located in Brasilia and is consisted by four inclined spans (access ramps) of $51.2 \mathrm{~m}$ in length, four horizontal ones, which two of them are $31.3 \mathrm{~m}$ and the other two are $34.1 \mathrm{~m}$ (Figure 1). The spans are joined by circular structures (mushrooms), consisting of a slab supported on a pillar, both of reinforced concrete. (Figure 2). The analysed footbridge crosses a road named E.P.I.A (Estrada Parque Indústria e Abastecimento). The footbridge is made up of two flat steel trusses $2.4 \mathrm{~m}$ distant and connected by cross steel beams as well. The photo below (Figure 3 ) shows the roof and the floor of the footbridge. The roof is formed by curved plates made out of reinforced mortar of about $2.8 \mathrm{~m}$ in length, $2.4 \mathrm{~m}$ wide and $2.0 \mathrm{~cm}$ of thickness. The roof is supported on the metallic upper horizontal elements of the trusses. The floor of the footbridge is composed of reinforced concrete shells of $0.4 \mathrm{~m}$ wide, $0.03 \mathrm{~m}$ in thickness and approximately $2.8 \mathrm{~m}$ in length. 


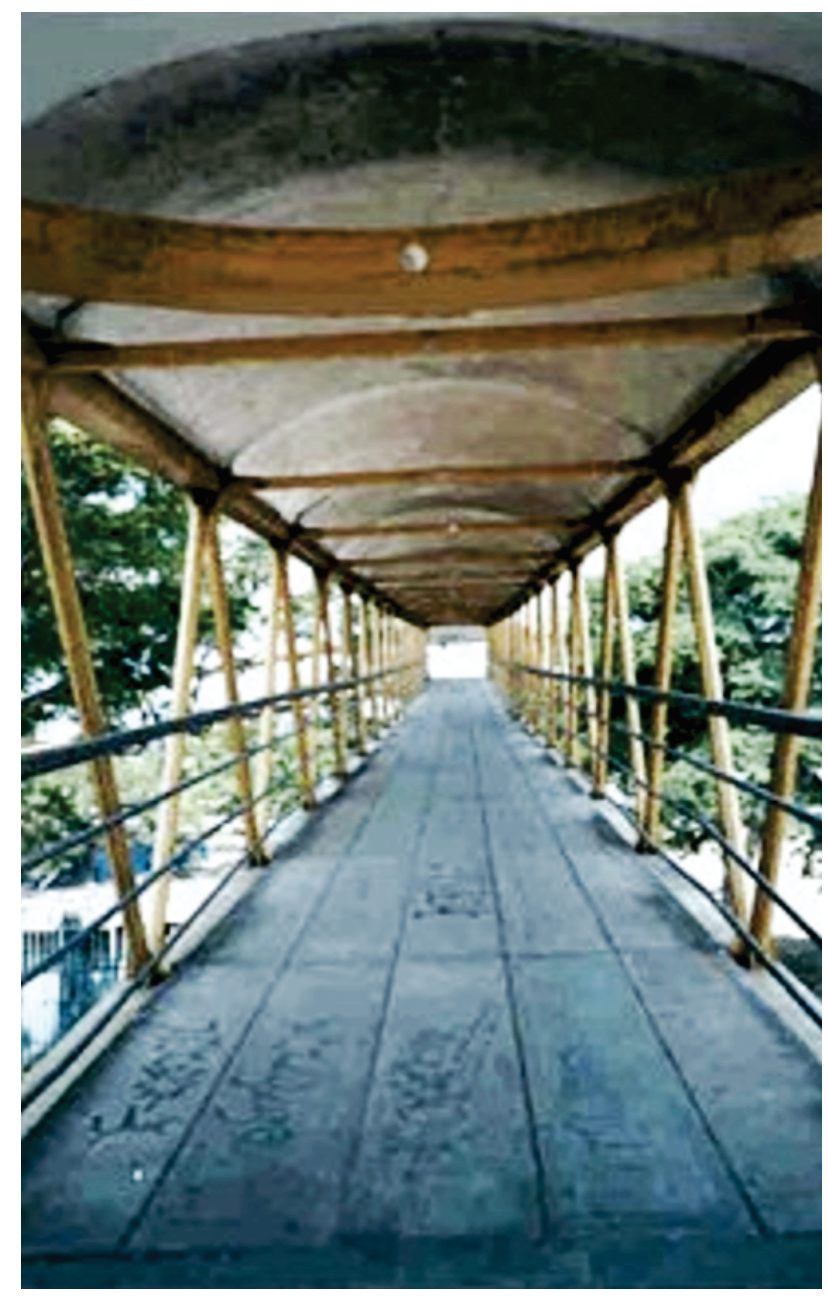

Figure 3

Details of the roof and the floor

\section{Field tests}

A series of experimental tests were held to identify the frequencies, mode shapes, and damping of the footbridge. The accelerations

\section{Table 1}

Natural vertical frequencies, Brasiliano et al. [9]

\begin{tabular}{|c|c|c|}
\hline Frequencies & SSI-COV/ref $(\mathbf{H z})$ & SSI-DATA/ ref $(\mathbf{H z})$ \\
\hline $1^{\text {st }}$ & 3.92 & 3.94 \\
\hline $2^{\text {nd }}$ & 10.08 & 10.11 \\
\hline
\end{tabular}

found at the points indicated in Figure 4 allowed to obtain the dynamic properties applying two stochastic identification methods in time domain, the SSICOV/ref and the SSI-DATA/ref.

The main goal of the modal tests was to identify the first vertical, lateral and torsional vibration modes of the footbridge. Thus, the accelerations were recorded on the footbridge's floor at the points indicated in the Figure 4. The instrumentation of the structure consisted of nine piezoelectric accelerometers, four of them with sensitivity of $0.16 \mathrm{mV} / \mathrm{g}$ and five of them with sensitivity of $103.8 \mathrm{mV} / \mathrm{g}$, which were used to collect the vertical and lateral accelerations at the points corresponding to the first reference line (See Figure 4). On the first line of reference, three of the most sensitive accelerometers were placed: one in the horizontal direction and two in the vertical direction, being one of these vertical placed in each border. About the remaining two highsensitivity accelerometers, one was placed on the reference line in horizontal direction, and the other was used to measure the acceleration in the horizontal direction as well as in the other measurement points. In each step of the modal tests, nine acceleration records were acquired.

The force generated by two pedestrians walking side by side, hammer and jump impacts were used to excite the footbridge. The sampling frequency used was $200 \mathrm{~Hz}$ and signals were recorded during 15 seconds.

The first two vertical mode shapes were obtained from the accelerations records and using the previously methods mentioned (Table 1 and Figure 5). The power spectral density functions were later obtained from the acceleration records in an attempt to identify the lateral and torsional frequencies that had not been obtained with the time domain methods. However, the lateral and torsional modes were not accurately identified.

In order to obtain the frequencies corresponding to the lateral and torsional modes, the response signals were processed, thus obtaining the power spectral density functions which are indicated

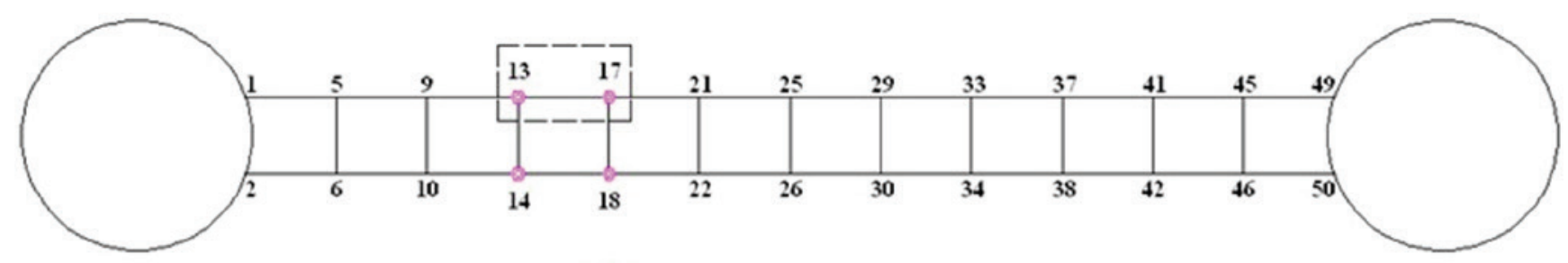

(ㅇ) Reference accelerometers

1st reference line $=$ nodes 13 and 14

2nd reference line $=$ nodes 17 and 18

Figure 4

Scheme of the horizontal span tested on instrumented points (modified from Brasiliano et al. [9]) 


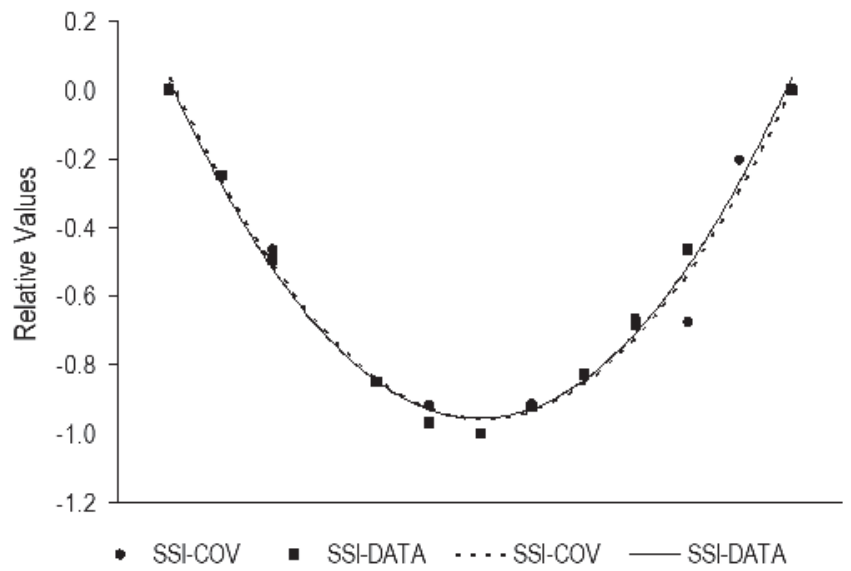

(a)

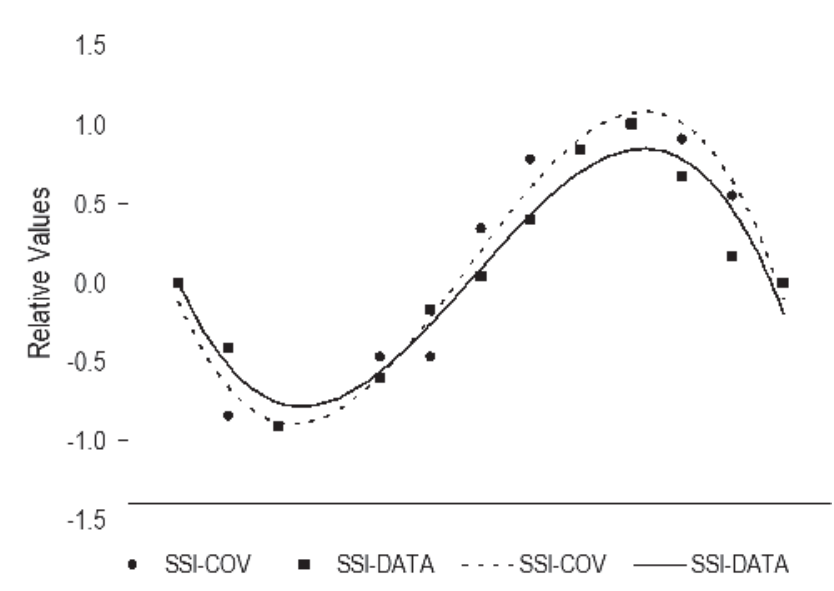

(b)

\section{Figure 5}

Experimental results corresponding to (a) first vertical mode shape $(3.9 \mathrm{~Hz})$ and to (b) second vertical mode shape $(10.1 \mathrm{~Hz})$, Brasiliano et al. [9]

in the figures 6 and 7 . The achieved results in all the points enabled to identify the first lateral frequency of the footbridge about $3.12 \mathrm{~Hz}$. A second peak appeared around $5.18 \mathrm{~Hz}$. In the torsion's case, the power spectral density function, Figure 7 , illustrates two peaks, one around $8.23 \mathrm{~Hz}$ and the other around $11.35 \mathrm{~Hz}$.

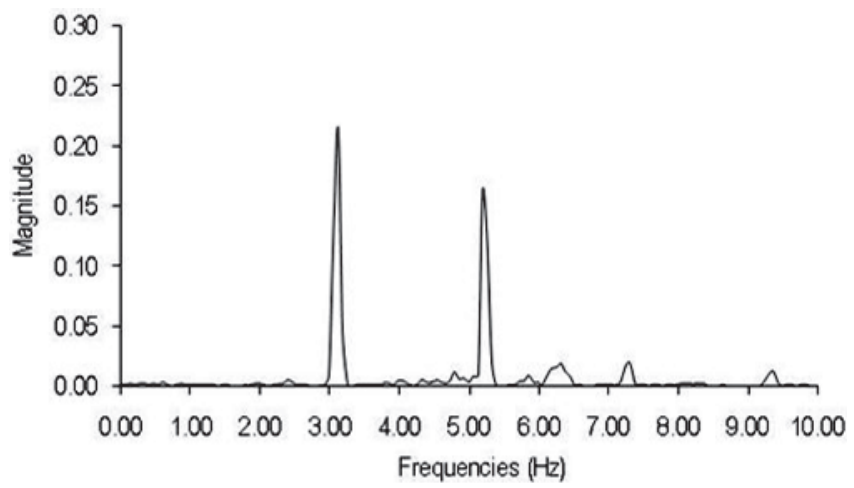

\section{Figure 6}

Power spectral density function for lateral direction, Brasiliano et al. [9]

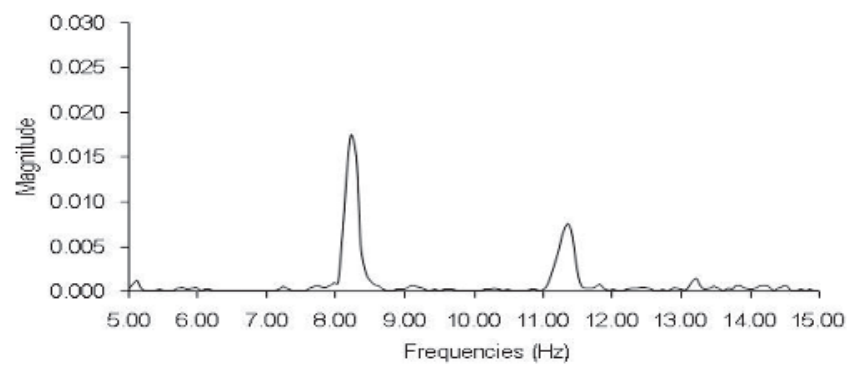

\section{Figure 7}

Power spectral density function for torsion direction, Brasiliano et al. [9]
A second series of experimental tests was carried out (Brito et al. [10]), and the excitation applied was through the impacts produced by pedestrians in both lateral and vertical directions. Thus, complementing the results obtained previously. A synthesis of the main experimental results is illustrated in the Table 2.

From the results presented in the Table 2 it is possible to verify that regarding the value of the 1st vertical frequency there was a discrete reduction in comparison to the one previously published by Brasiliano et al. [9]. Such variation is related to the increase of mass placed on the footbridge's roof, along the entire span, due to a repair carried out on the structure.

\section{Discussion of the numerical models and results}

In order to give insight on the modeling evolution and to explore the results obtained, several numerical models were created, which are presented and discussed below, in an attempt of representing the dynamic behavior observed in the experimental tests (Santos [11]).

\subsection{Model 1 proposed by Gomes [12]}

In the first model, the metallic structural elements were modeled as elements of a space frame, with designated for BEAM4 (ANSYS [13]). The floor was discretized by using four-node shell element

Table 2

Natural frequencies identified experimentally

\begin{tabular}{|c|c|c|c|c|}
\hline \multicolumn{3}{|c|}{ First set of tests } & \multicolumn{2}{c|}{ Second set of tests } \\
\hline Direction & $\begin{array}{c}\text { First } \\
\text { frequency } \\
\text { (Hz) }\end{array}$ & $\begin{array}{c}\text { Second } \\
\text { frequency } \\
(\mathbf{H z})\end{array}$ & $\begin{array}{c}\text { First } \\
\text { frequency } \\
\text { (Hz) }\end{array}$ & $\begin{array}{c}\text { Second } \\
\text { frequency } \\
(\mathbf{H z})\end{array}$ \\
\hline Vertical & 3.93 & 10.10 & 3.55 & 10.08 \\
\hline Lateral & 3.12 & 5.18 & 2.49 & 4.25 \\
\hline Torsional & 8.23 & 11.35 & 7.55 & 8.88 \\
\hline
\end{tabular}




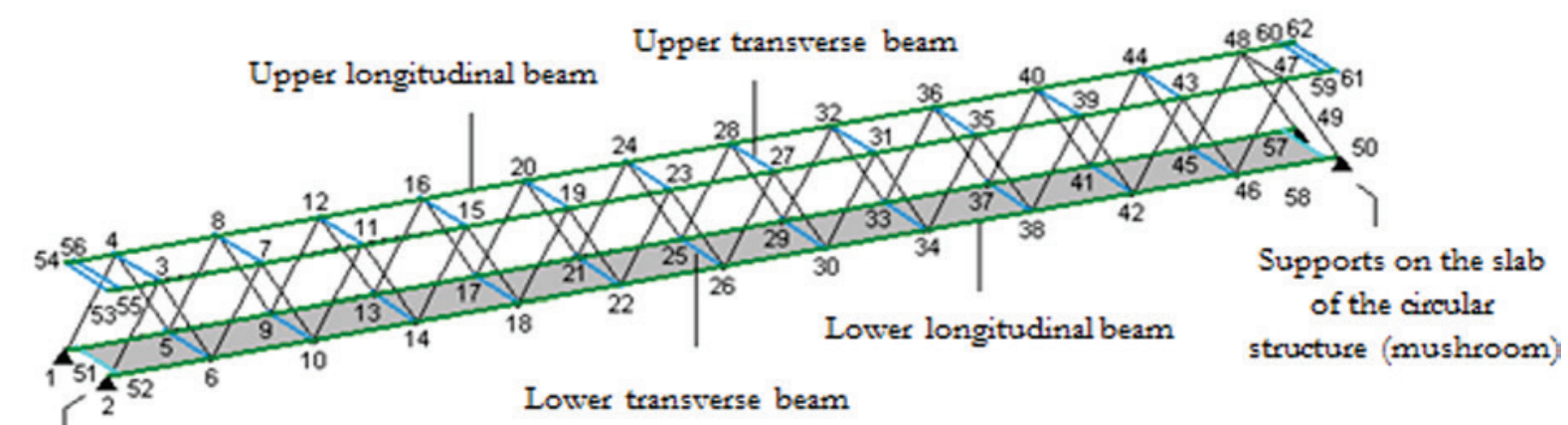

\author{
Supports on the slab \\ of the circular
}

structure (mushroom)

\title{
Figure 8
}

Discretization applied (modified from Gomes [12])

with linear displacement, identified by SHELL63 (ANSYS [13]) and the roof was considered as a distributed mass acting on the upper horizontal elements of the truss. The handrail and guardrail were modeled as concentrated masses on the flat trusses' lower nodes, with elements of type MASS21 (ANSYS [13]). The discretization used is shown in Figure 8.

The mechanical properties of the materials considered in this analysis are presented in Table 3. From these choices the results of this first model are summarized in Table 4.

\subsection{Model 2 proposed by Brasiliano et al. [9]}

In the previous model the deck was modeled ongoing basis and considered as shell elements which are supported on the lower horizontal elements of the truss. However, there are doubts about its contribution to the deck stiffness. Similarly, the doubts about the discretization of the roof led to two new models, and always considering the metal trellises as elements of a space frame.

In the first model, the deck was considered as a concentrated mass and the roof as a distributed mass along the longitudinal beams, while the handrail and guardrail were considered concentrated masses supported in the lower horizontal elements of the truss. The second model considered the deck modelled with shell elements maintaining the discretization already used for the other elements. The values of the elasticity modulus of the materials have been adjusted.

Based on the available experimental results, an update of the model was made by modifying the elasticity modulus of the considered steel. So, for the model that considers the deck as shell elements, the elasticity modulus was reduced to $1.72 \times 10^{11} \mathrm{~N} / \mathrm{m}^{2}$, and in the other model to $1.66 \times 10^{11} \mathrm{~N} / \mathrm{m}^{2}$. The results presented by Brasiliano et al. [9] are also presented here for the sake of clarity (see Tables 5 and 6 ).

As noted in Brasiliano et al. [9], by comparing the vertical natural frequencies from both models, it can be observed that the modeling of the deck has not influenced the vertical frequencies. A simplified model in which the deck and roof are represented as massonly components is sufficient in terms of obtaining a satisfactory performance of the vertical dynamic behavior of the footbridge. In terms of the performance of the models for the lateral direction, the modeling of the deck heavily affected the results, by comparing the lateral natural frequencies obtained by modeling the deck as mass-only and as a shell. A comparison of the results shown in Tables 5 and 6 also shows that the torsional modes were also affected by the modeling of the deck.

\subsection{Model 3 proposed by Santos [14]}

In this modeling, all the metal elements that compose the truss, such as the diagonals, lower and upper chords, lower and upper crossbars (sleepers) were modeled as elements of a space frame. On the other hand, the deck and the roof were considered shell elements. The handrail and the guardrail were discretized through concentrated mass elements. In the first model (Table 7) the material properties were identical to those adopted by Gomes [12]. The second one (Table 8 ) the elasticity modulus of the trusses' steel bars was reduced to $1.72 \times 10^{11} \mathrm{~N} / \mathrm{m}^{2}$ according to the value used by Brasiliano et al. [9]. In this way, Santos [14] advanced in relation to the previously developed models updating them through two techniques: sub-problem approach and method of first order, ranging the values of physical properties. The results obtained are shown in tables 7 and 8 .

In terms of torsional and lateral frequencies, both models 1 and 2 better approximate the results obtained experimentally. The second model yet is the most interesting when comparing the other frequencies. In order to update the second model, a sensitivity analysis is initially made to define the upgrading parameters.

\section{Table 3}

Materials properties

\begin{tabular}{|c|c|c|}
\hline Materials & $\begin{array}{c}\text { Modulus of } \\
\text { elasticity }\left(\mathbf{N} / \mathrm{m}^{2}\right)\end{array}$ & $\begin{array}{c}\text { Specific weight } \\
\left(\mathrm{kN} / \mathrm{m}^{3}\right)\end{array}$ \\
\hline Steel SAC 41 & $2.074 \times 10^{11}$ & 78.6 \\
\hline $\begin{array}{c}\text { Reinforced } \\
\text { concrete }\end{array}$ & $2.9 \times 10^{10}$ & 25.0 \\
\hline
\end{tabular}


Thus, making it possible to verify that the elasticity modulus of the metallic elements was one of the parameter that changed the dependent variables the most. Followed by the elasticity modulus of the roof's plate, the specific mass and deck plates.

The updating according to the two methods predicted in the computational program used, the approximation by sub-problem

\section{Table 4}

Frequencies and mode shapes

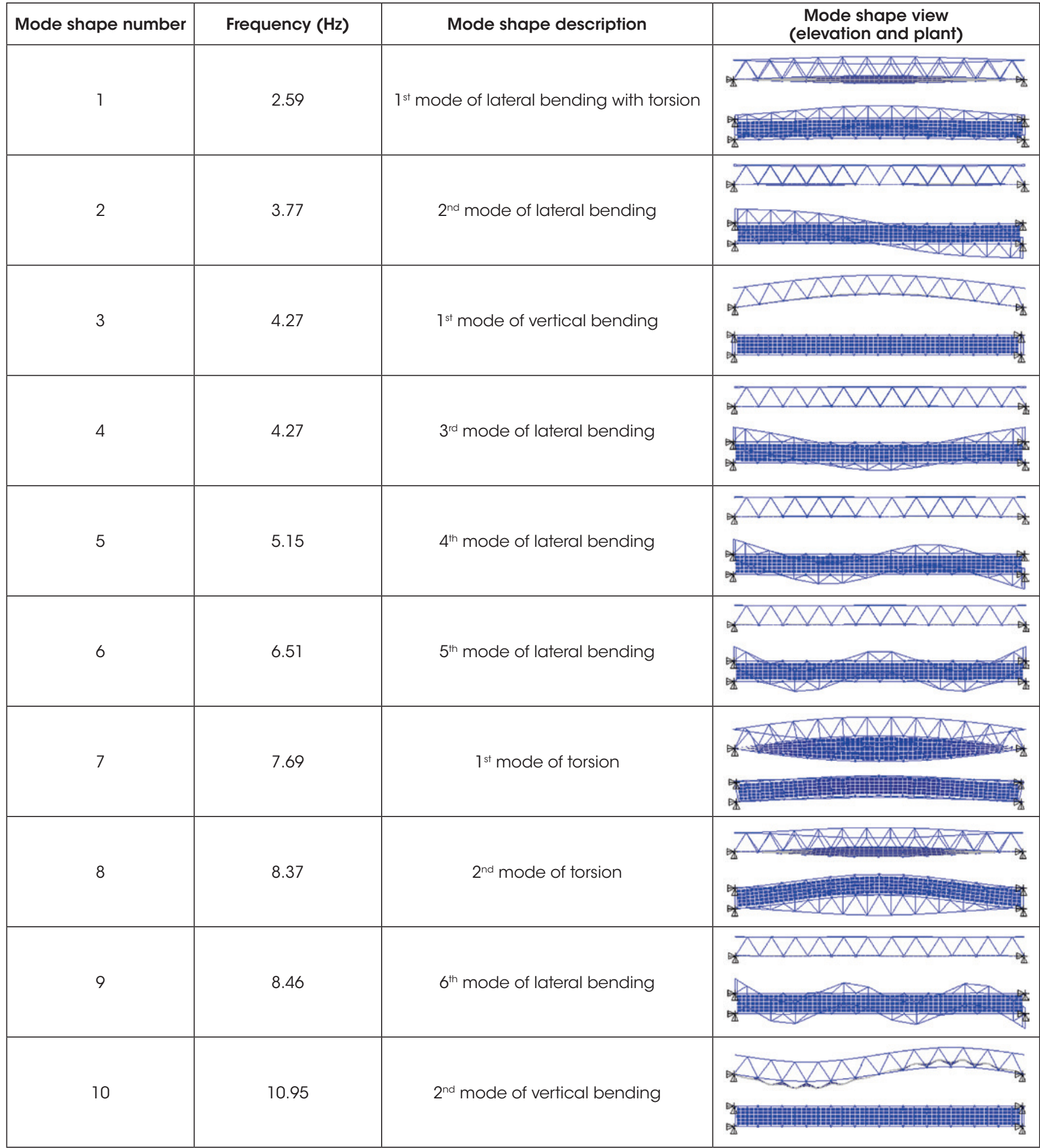


and the first order method, led to obtaining the updated parameters that are indicate in Table 9.

From this update the results indicated in Table 10 were obtained, and the FER index used to determine the correlation between numerical and experimental frequencies was calculated as:

$F E R_{g h}=\frac{\lambda_{h}-\lambda_{g}}{\lambda_{g}}$

where $\lambda_{h}$ represents the natural frequency of the numerical mode $h$ and $\lambda_{g}$ represents the natural frequency of the experimental mode $g$. The new models that arise from the updating process enabled to obtain values of frequencies near to the experimental ones for torsional modes, and partially for the lateral ones.

\subsection{Model proposed by Santos [11]}

The model proposed by Santos [11] was based on a basic model that properly represented the experimental frequencies obtained. It worked with SAP software [15] and, in the model, the metal pieces were represented by frame elements with rigid joints, thus representing the welded connections of the real structure. The deck in reinforced concrete and the roof in reinforced mortar were modeled by shell elements. The columns were represented by labeled supports at the ends of the truss beams. The handrail and guardrail bars were considered as nodal mass elements applied at the points of intersection with the structure's diagonals. The model was calibrated by trials and errors, manually adjusting some parameters in order to obtain the values of natural frequencies closer to the experimental results. They are: reinforced mortar, thickness of the deck slabs, and cross section. The specific weight of the roof's reinforced mortar and of the reinforced concrete was the same: $25 \mathrm{kN} / \mathrm{m}^{3}$. The equivalent height of the deck's slab section was changed from $5.25 \mathrm{~cm}$ to $6.0 \mathrm{~cm}$. Additionally, the truss' diagonal was modeled as a circular section equivalent of

\section{Table 5}

Frequencies and mode shapes description obtained for the model in which the deck was modeled as mass. (Brasiliano et al. [9])

\begin{tabular}{|c|c|}
\hline Frequency $(\mathrm{Hz})$ & Mode shape description \\
\hline 0.857 & $1^{\text {st }}$ Lateral mode with movement of the deck \\
\hline 1.816 & $2^{\text {nd }}$ Lateral mode with movement of the deck \\
\hline 2.797 & Lateral mode with torsion (torsional and lateral movement of the deck) \\
\hline 3.131 & Torsional mode with movement of the deck \\
\hline 3.697 & Lateral mode with movement of the deck \\
\hline 3.917 & $1^{\text {st }}$ vertical mode \\
\hline 4.596 & Lateral mode with movement of the deck \\
\hline 4.838 & Lateral mode with movement of the deck \\
\hline 5.921 & Lateral mode with movement of the deck \\
\hline 6.181 & Lateral mode with movement of the deck \\
\hline 6.952 & $1^{\text {st }}$ Pure torsional mode \\
\hline 7.676 & Lateral mode with movement of the deck \\
\hline 7.892 & Lateral mode with movement of the deck \\
\hline 9.786 & Lateral mode with movement of the deck \\
\hline 9.848 & 2 \\
\hline
\end{tabular}

\section{Table 6}

Frequencies and mode shapes description obtained for the model in which the deck was modeled as shell elements. (Brasiliano et al. [9])

\begin{tabular}{|c|c|}
\hline Frequency $(\mathrm{Hz})$ & Mode shape description \\
\hline 2.370 & Torsional mode of the deck with lateral bending of the trusses \\
\hline 3.442 & $2^{\text {nd }}$ Lateral mode of the trusses (deck remained stopped) \\
\hline 3.900 & $3^{\text {rd }}$ Lateral mode of the trusses (deck remained stopped) \\
\hline 3.923 & $1^{\text {st }}$ vertical mode \\
\hline 4.694 & $4^{\text {th }}$ Lateral mode of the trusses (deck remained stopped) \\
\hline 5.928 & $5^{\text {th }}$ Lateral mode of the trusses (deck remained stopped) \\
\hline 7.073 & Lateral mode with torsion (torsion of the deck and lateral movement of the deck and trusses) \\
\hline 7.711 & $6^{\text {th }}$ lateral mode of the trusses (deck remained stopped) \\
\hline 7.853 & $\begin{array}{c}\text { Lateral mode with torsion (torsion of the deck and lateral } \\
\text { movement of the deck and trusses in opposite directions) }\end{array}$ \\
\hline 10.096 & $7^{\text {th }}$ lateral mode of the trusses (deck remained stopped) \\
\hline 10.254 & \multicolumn{2}{|c|}{$2^{\text {nd }}$ vertical mode } \\
\hline
\end{tabular}


$70 \mathrm{~mm}$ in diameter and $6.7 \mathrm{~mm}$ in thickness. The main results are shown in the Table 11. A good approximation can be observed in comparison to the experimental results. Finally, Table 12 illustrates the comparison of the main results found.

\section{Conclusions}

The results presented indicate that basic modeling closely matches the vertical frequencies, as the models proposed by Brasiliano et al. [9] (see Table 12), without highlighting the need for more accurate modeling. In regard to the lateral frequencies there is also a reasonable approach with simpler models but requires the deck's modeling to be as a structural element. On the other hand in relation to the torsional frequencies identified experimentally, there is a greater difficult to obtain close results with simpler models, thus making it necessary to perform updates of several parameters. From the results showed in Table 12, the models which the torsional and lateral behavior could be better represented were the proposed by Gomes [12], and the one of Brasiliano et al. [9] which the deck was considered as concentrated mass. It is worth noting, however, that the lateral and torsional modes could not be experimentally identified, so there is no complete information on these one.

About the natural experimental frequencies showed in Table 2, identified from the two realized tests (Brasiliano et al. [9] and Brito et al. [10]), it can be observed a decrease in its values for the three considered directions. As commented before, this variation occurred probably due to a repair that has been

Table 7

Analysis of free vibrations of the footbridge on E.P.I.A. (Estrada Parque Indústria e Abastecimento) - Model 1

\begin{tabular}{|c|c|c|c|}
\hline Mode shapes & Frequency $(\mathrm{Hz})$ & Mode shape description & Mode shape view \\
\hline $1^{\text {st }}$ & 2.147 & Deck torsional, roof and truss with lateral movement & \\
\hline $2^{\text {nd }}$ & 4.353 & $1^{\text {st }}$ vertical mode & \\
\hline $3^{\text {rd }}$ & 5.226 & Roof's lateral mode (deck remain static) & \\
\hline $4^{\text {th }}$ & 6.430 & Roof's torsional lateral mode, torsional deck & \\
\hline $5^{\text {th }}$ & 8.206 & Roof's torsional lateral mode, remains static & \\
\hline $6^{\text {th }}$ & 10.779 & $2^{\text {nd }}$ vertical mode & \\
\hline $7^{\text {th }}$ & 12.286 & Roof's torsional lateral mode, torsional deck & \\
\hline $8^{\text {th }}$ & 12.826 & Roof's torsional lateral mode, torsional deck & \\
\hline $9^{\text {th }}$ & 14.687 & $3^{\text {rd }}$ deformed vertical mode & \\
\hline $10^{\text {th }}$ & 15.782 & $\begin{array}{l}4^{\text {th }} \text { deformed vertical mode deck, } \\
\text { roof without deformation }\end{array}$ & \\
\hline
\end{tabular}




\section{Table 8}

Analysis of free vibrations of the footbridge on E.P.I.A. (Estrada Parque Indústria e Abastecimento) Model $2\left(E=1.72 \times 10^{11} \mathrm{~N} / \mathrm{m}^{2}\right)$

\begin{tabular}{|c|c|c|c|}
\hline Mode shapes & Frequency $(\mathrm{Hz})$ & Mode shape description & Mode shape view \\
\hline $7^{\text {st }}$ & 1.976 & Deck torsional, roof and truss with lateral movement & \\
\hline $2^{\text {nd }}$ & 4.070 & $1^{\text {st }}$ vertical mode & \\
\hline $3^{\text {rd }}$ & 4.932 & Roof's lateral mode (deck remain static) & \\
\hline $4^{\text {th }}$ & 5.989 & Roof's torsional lateral mode, torsional deck & \\
\hline $5^{\text {th }}$ & 7.690 & Roof's torsional lateral mode, remains static & \\
\hline $6^{\text {th }}$ & 10.117 & $2^{\text {nd }}$ vertical mode & \\
\hline $7^{\text {th }}$ & 11.675 & Roof's torsional lateral mode, torsional deck & \\
\hline $8^{\text {th }}$ & 12.328 & Roof's torsional lateral mode, torsional deck & \\
\hline $9^{\text {th }}$ & 13.950 & $3^{\text {rd }}$ deformed vertical mode & \\
\hline $10^{\text {th }}$ & 15.262 & $\begin{array}{l}4^{\text {th }} \text { deformed vertical mode deck, } \\
\text { roof without deformation }\end{array}$ & \\
\hline
\end{tabular}

\section{Table 9}

Updated parameters - optimal project - Santos [14]

\begin{tabular}{|c|c|c|c|c|}
\hline \multirow{2}{*}{ Updated parameters } & Unit & Initial model & $\begin{array}{c}|c| \\
\text { Upproximation by } \\
\text { sub-problem method }\end{array}$ & First order method \\
\hline $\begin{array}{c}\text { Deck plate's specific } \\
\text { mass }\end{array}$ & $\mathrm{Kg} / \mathrm{m}^{3}$ & 2548.42 & 2600.85 & 2748.85 \\
\hline $\begin{array}{c}\text { Elasticity modulus } \\
\text { of the deck's plate }\end{array}$ & $\mathrm{N} / \mathrm{m}^{2}$ & $2.90 \times 10^{10}$ & $2.9838 \times 10^{10}$ & $2.9862 \times 10^{11}$ \\
\hline $\begin{array}{c}\text { Specific mass of } \\
\text { the roof's plate }\end{array}$ & $\mathrm{Kg} / \mathrm{m}^{3}$ & 2242.60 & 2397.84 & 2551.13 \\
\hline $\begin{array}{c}\text { Elasticity modulus } \\
\text { of the roof's plate }\end{array}$ & $\mathrm{N} / \mathrm{m}^{2}$ & $5.0 \times 10^{9}$ & $5.1115 \times 10^{9}$ & $5.7346 \times 10^{9}$ \\
\hline Steel's specific mass & $\mathrm{Kg} / \mathrm{m}^{3}$ & 8012.23 & 8138.29 & 8425.59 \\
\hline $\begin{array}{c}\text { Steel's elasticity } \\
\text { modulus }\end{array}$ & $\mathrm{N} / \mathrm{m}^{2}$ & $1.72 \times 10^{11}$ & $1.7181 \times 10^{11}$ & $1.7922 \times 10^{11}$ \\
\hline
\end{tabular}


made on the roof of the footbridge. Such repair has included an increase of mass along the entire monitored span. The greatest differences can be verified for the lateral and torsional frequencies, which were the directions more difficult to excite. These differences were about $20 \%$.

The NBR 6118 [15] establishes that footbridges are considered to

\section{Table 10}

Experimental and numerical natural frequencies and FER indexes to the vertical modes numerical model and optimal project based on the first experimental tests

\begin{tabular}{|c|c|c|c|c|c|c|c|}
\hline $\begin{array}{c}\text { Mode } \\
\text { number }\end{array}$ & $\begin{array}{c}\text { Mode } \\
\text { description }\end{array}$ & $\begin{array}{c}\text { Frequency } \\
\text { (Hz) } \\
\text { (first } \\
\text { experimental) }\end{array}$ & $\begin{array}{c}\text { Frequency } \\
\text { (Hz) } \\
\text { (initial model) }\end{array}$ & $\begin{array}{c}\text { Frequency (Hz) } \\
\text { (approximation } \\
\text { by sub- } \\
\text { problem) }\end{array}$ & $\begin{array}{c}\text { FER (\%) } \\
\text { (approximation } \\
\text { by sub-problem) }\end{array}$ & $\begin{array}{c}\text { Frequency } \\
\text { (Hz) } \\
\text { (first order) }\end{array}$ & $\begin{array}{c}\text { FER (\%) } \\
\text { (first order) }\end{array}$ \\
\hline $1^{\text {st }}$ & $1^{\text {st }}$ lateral & $3.12-2.49$ & 1.976 & 1.924 & $-38.33 \%$ & 1.915 & $-38.62 \%$ \\
\hline $2^{\text {nd }}$ & $1^{\text {st }}$ vertical & $3.93-3.55$ & 4.070 & 4.010 & $2.04 \%$ & 4.025 & $2.42 \%$ \\
\hline $3^{\text {rd }}$ & - & - & 4.932 & 4.815 & - & 4.832 & - \\
\hline $4^{\text {th }}$ & $2^{\text {nd }}$ lateral & $5.18-4.25$ & 5.989 & 5.874 & $13.40 \%$ & 5.876 & $13.44 \%$ \\
\hline $5^{\text {th }}$ & $1^{\text {st }}$ torsional & $8.23-7.55$ & 7.690 & 7.632 & $-7.27 \%$ & 7.581 & $-7.89 \%$ \\
\hline $6^{\text {th }}$ & $2^{\text {nd }}$ vertical & $10.095-10.08$ & 10.117 & 9.997 & $-0.97 \%$ & 9.947 & $-1.47 \%$ \\
\hline $7^{\text {th }}$ & $2^{\text {nd }}$ torsional & $11.35-8.88$ & 11.675 & 11.428 & $0.69 \%$ & 11.506 & $1.37 \%$ \\
\hline $8^{\text {th }}$ & - & - & 12.328 & 12.098 & - & 12.241 & - \\
\hline $9^{\text {th }}$ & - & - & 13.950 & 13.867 & - & 13.691 & - \\
\hline $10^{\text {th }}$ & - & - & 15.262 & 15.238 & - & 14.944 & - \\
\hline
\end{tabular}

\section{Table 11}

Frequencies and mode shapes - Santos [14]

\begin{tabular}{|c|c|c|c|}
\hline \multirow{2}{*}{ Mode number } & \multirow{2}{*}{ Mode description } & Natural frequency [Hz] \\
\cline { 3 - 4 } & & Numerical model Santos [11] & $\begin{array}{c}\text { Experimental tests (Brasiliano } \\
\text { et al. [9] - Brito et al. [10]) }\end{array}$ \\
\hline $1^{\text {st }}$ & $1^{\text {st }}$ vertical & 4.14 & $3.90-3.55$ \\
\hline $2^{\text {nd }}$ & $2^{\text {nd }}$ vertical & 10.26 & $10.1-10.08$ \\
\hline $3^{\text {th }}$ & $1^{\text {st }}$ lateral & 2.57 & $3.12-2.49$ \\
\hline $4^{\text {th }}$ & $2^{\text {nd }}$ lateral & 6.41 & $5.18-4.25$ \\
\hline $5^{\text {th }}$ & $1^{\text {st }}$ torsional & 6.59 & $8.23-7.55$ \\
\hline
\end{tabular}

\section{Table 12}

Comparison of the results of natural frequencies obtained from free vibration analysis of the horizontal span footbridge over the E.P.I.A. (Estrada Parque Indústria e Abastecimento)

\begin{tabular}{|c|c|c|c|c|c|c|c|c|}
\hline $\begin{array}{c}\text { Mode } \\
\text { shapes }\end{array}$ & $\begin{array}{l}\text { Freq. (Hz) } \\
\text { exp. }\end{array}$ & $\begin{array}{c}\text { Gomes [12] } \\
\text { Space } \\
\text { frame }+ \\
\text { roof mass + } \\
\text { deck's plate }\end{array}$ & $\begin{array}{l}\text { Brasiliano et. } \\
\text { al. [9] } \\
\text { Space frame } \\
\text { + deck's } \\
\text { concentrated } \\
\text { mass + roof's } \\
\text { distributed } \\
\text { mass }\end{array}$ & $\begin{array}{l}\text { Brasiliano } \\
\text { et. al. [9] } \\
\text { Space } \\
\text { frame + } \\
\text { deck's shell } \\
\text { elements } \\
\text { + roof's } \\
\text { distributed } \\
\text { mass }\end{array}$ & $\begin{array}{c}\text { Santos [14] } \\
1 \\
\text { Space } \\
\text { frame + } \\
\text { deck's } \\
\text { plate and } \\
\text { roof elast. } \\
\text { modulus } \\
2.07 \times 10^{11} \\
\end{array}$ & $\begin{array}{c}\text { Santos [14] } \\
2 \\
\text { Space } \\
\text { frame + } \\
\text { deck's } \\
\text { plate and } \\
\text { roof elast. } \\
\text { modulus } \\
1.72 \times 10^{11} \\
\end{array}$ & $\begin{array}{l}\text { Santos [14] } \\
\text { Updated } \\
\text { model } 2 \text { - } \\
\text { first order }\end{array}$ & $\begin{array}{c}\text { Santos [11] } \\
\text { Interligated } \\
\text { bars } \\
\text { elements + } \\
\text { elem. deck's } \\
\text { plate and } \\
\text { roof }\end{array}$ \\
\hline $1^{\text {st }} \mathrm{V}$ & $3.93-3.55$ & 4.2716 & 3.917 & 3.923 & 4.3539 & 4.0707 & 4.025 & 4.14 \\
\hline $2^{\text {nd }} V$ & $10.10-10.08$ & 10.95 & 9.848 & 10.254 & 10.779 & 10.117 & 9.947 & 10.26 \\
\hline \multirow[t]{2}{*}{$1^{\text {st }} \mathrm{H}$} & $3.12-2.49$ & 2.59 & 0.857 & $\begin{array}{c}\text { (not } \\
\text { identified) }\end{array}$ & 2.57 & 2.57 & 2.57 & 2.57 \\
\hline & 2.1473 & 1.976 & 1.915 & 2.57 & 6.41 & 6.41 & 6.41 & 6.41 \\
\hline $2^{\text {nd }} \mathrm{H}$ & $5.18-4.25$ & 3.77 & 1.816 & $3.442-7.853$ & 6.4300 & 5.9893 & 5.876 & 6.41 \\
\hline $1^{\text {st }} \mathrm{T}$ & $8.23-7.55$ & 7.69 & $\begin{array}{c}6.952 \\
\text { (torsional } \\
\text { mode) }\end{array}$ & - & - & - & - & 6.59 \\
\hline $2^{\text {nd }} T$ & $11.35-8.88$ & 8.37 & $\begin{array}{c}\text { (not } \\
\text { identified) }\end{array}$ & - & - & - & - & - \\
\hline
\end{tabular}


be satisfactory in terms of vibration performance if the fundamental frequency in vertical direction only is above $5.4 \mathrm{~Hz}$ ( $f>1.2^{*}$ fcritical - fcritical $=4.5 \mathrm{~Hz}$ ). On the other hand, the first two harmonics of walking excitation, considering the pedestrian pacing rate as the first harmonic, are typically in the range from 1.6 to $2.4 \mathrm{~Hz}$ for vertical direction. For the lateral direction the first harmonic of excitation is around $1.0 \mathrm{~Hz}$. Once the values identified for the vertical and lateral fundamental frequencies were $3.93 \mathrm{~Hz}-3.55 \mathrm{~Hz}$ and $3.12 \mathrm{~Hz}-2.49 \mathrm{~Hz}$ (see Table 2), respectively, in terms of the performance of this structural system for vibration serviceability applications, it is observed that the natural frequencies, both in vertical and lateral directions, are out the critical frequency range of the first harmonic of pedestrian pacing rates. The system is thus robust for medium span lengths of the order from $30 \mathrm{~m}$ to $40 \mathrm{~m}$. Despite its importance, the displacements amplitude has not been evaluated in this study.

This paper also tried to show that a suitable modelling has a relevant importance on the project and use of structures in a general way. Highlighting that a simple model which well represents the behavior of a structure is always useful by the ease of use.

\section{Acknowledgements}

The authors gratefully acknowledge the financial support of CAPES and CNPq (Brazil), which made this research possible.

\section{References}

[1] British Standards Institute. 1978. BS5400 British Standards - Steel, concrete and composite bridges: specification for loads, Part 2, Appendix C. London.

[2] Ontario Highway Bridge Design Code. 1983. Ministry of Transportation and Communications, Highway Engineering Division, Ontario, Canada.

[3] British Standards Institute. 2008. UK National Annex to Eurocode 1: Actions on structures -Part 2: Traffic loads on bridges. NA to BS EN 1991-2:2003. London.

[4] Hivoss - Human Induced Vibration of Steel Structures: Design of Footbridges Guideline 2008. Research Fund for Coal and Steel. RFS2-CT-2007-00033.

[5] Dallard P, Fitzpatrick AJ, Flint A, Bourva S, Low A, Smith RMR et al. The London Millennium footbridge. The Structural Engineer; 79 (22):17-33, 2001.

[6] Danbon F, Grillaud G. Dynamic behaviour of a steel footbridge - Characterization and modelling of the dynamic loading induced by a moving crowd on the Solferino footbridge in Paris. Footbridge 2005 - Second International Conference, 2005.

[7] Matsumoto, Y.; Sato, S.; Nishioka, T.; Shiojiri, H. A Study on Dynamic Design of Pedestrian Over-Bridges, Transaction of JSCE 4, 50-51, 1972.

[8] CEB - Comitê Euro-International Du Beton (1991). Bulletin D'Information No. 209, August.

[9] Brasiliano, A.; Doz, G.; Brito, J. L. V. and Pimentel, R. Role of Non-Metallic Components on the Dynamic Behaviour of Composite Footbridges. Third International Conference Footbridges 2008.
[10] Brito, J. L. V.; Doz, G. N.; Ávila, S. M.; Pimentel, R. L.; Brasiliano, A.; Roitman, N.; Magluta, C.; Barbosa, F. S.; Nogueira, F. M. A. Avaliação do Comportamento Dinâmico de Passarela Composta Localizada em Brasília, Jornadas Sudamericanas de Ingeniería Estructural, San Juan, Argentina, 2010.

[11] Santos, C. M. Avaliação do comportamento dinâmico de uma passarela submetida a carregamentos induzidos por pedestres, Dissertação de Mestrado, UFRJ/COPPE, 123p., 2011.

[12] Gomes, D. H. M. - Controle da Resposta Dinâmica de uma Passarela de Pedestres da Cidade de Brasília com a Utilização de Amortecedores de Massa Sintonizados. Dissertação de Mestrado, Publicação: E.DM - 008A/06, Departamento de Engenharia Civil e Ambiental, Universidade de Brasília, Brasília, DF, xxi,174p., 2006.

[13] Referência [14] ANSYS versão 17.0 estudantil (2017). Reference Manual.

[14] Santos, I. C. Atualização do modelo numérico em elementos finitos de uma passarela de pedestres com base em dados experimentais. Dissertação de Mestrado, Publicação E.DM 010A/ 09, Departamento de Engenharia Civil e Ambiental, Universidade de Brasília, Brasília, DF, 136p., 2009.

[15] ABNT NBR 6118. (2014). "Projetos de Estruturas de Concreto - Procedimento", Norma Brasileira. 